Jurnal Ilmiah Matematika dan Pendidikan Matematika (JMP)

Vol. 10 No. 1, Juni 2018, hal. 39-52

ISSN (Cetak) : 2085-1456; ISSN (Online) : 2550-0422

\title{
REKOMBINASI MOLEKUL DNA
}

\author{
Isah Aisah \\ Departemen Matematika, Fakultas MIPA, Universitas Padjadjaran \\ isah.aisah@unpad.ac.id \\ Litani Farin N. \\ Departemen Matematika, Fakultas MIPA, Universitas Padjadjaran \\ Hendra S. Mulyana \\ Departemen Matematika, Fakultas MIPA, Universitas Padjadjaran
}

\begin{abstract}
Every living creature has unique genetic materials. These genetic materials are stored in a DNA molecule. In some cases, it is founda change in a normal DNA molecule into an abnormal one. Recombining DNA molecule is one way to solve this problem. In mathematical view, splicing system is a mathematical model of a system of a restriction enzyme's action in recombining DNA molecule. Splicing language is a language constructed by splicing system.Result obtained from double-chained DNA molecule recombination process using uniform splicing system and uniform splicing language is a various $L(S)$ language, which is depend on: (1) how we determine which DNA molecule that contains donor's and recipient's gen and (2) how we choose involved restriction enzyme. Apart from that, DNA molecule recombination can only be done on DNA molecule which has a DNA molecule's partition a restriction enzyme could identify.
\end{abstract}

Keywords : DNA, recombination, uniform splicing system, uniform splicing languages

\begin{abstract}
ABSTRAK. Setiap makhluk hidup memiliki materi genetik yang berbeda-beda.Materi genetik tersebut tersimpan di dalam suatu molekul DNA.Dalam beberapa kasus, ditemukan perubahan struktur suatu molekul DNA normal menjadi molekul DNA abnormal.Rekombinasi molekul DNA adalah cara untuk mengatasi masalah tersebut. Dalam bidang kajian matematika, splicing system merupakan model matematis dari sistem pada tindakan enzim restriksi dalam rekombinasi molekul DNA dan splicing language merupakan bahasa yang dihasilkan oleh splicing system.Hasil yang diperoleh dari proses rekombinasi molekul DNA rantai ganda menggunakan uniform splicing system dan uniform splicing language merupakan bahasa $L(S)$ yang berbeda-beda bergantung pada penentuan molekul DNA yang mengandung gen pendonor dan penerima donor serta pemilihan enzim restriksi yang terlibat. Selain itu, rekombinasi molekul DNA hanya dapat dilakukan pada molekul DNA yang memuat potongan molekul DNA yang dapat dikenali oleh suatu enzim restriksi.
\end{abstract}

Kata kunci : DNA, rekombinasi, uniformsplicing system, uniform splicing languages. 


\section{PENDAHULUAN}

Rekombinasi molekul DNA merupakan penyusunan kembali informasi genetik melalui proses penggabungan dua potongan molekul DNA dari molekul DNA yang merupakan calon gen pendonor dengan molekul DNA yang merupakan calon gen penerima donor. Kemudian hasil dari proses rekombinasi tersebut adalah molekul DNA baru.

Dalam kehidupan sehari-hari, rekombinasi molekul DNA lebih dikenal sebagai proses rekayasa genetika. Dalam hal ini, rekayasa genetika dilakukan untuk membuat molekul DNA yang abnormal menjadi molekul DNA yang normal.Contohnya adalah pada pembuatan hormon insulin untuk penderita diabetes dan pembuatan antibody pada vertebrata (ikan, amfibi, reptil, burung, dan mamalia).

Splicing system merupakan model matematis dari sistem dalam tindakan enzim restriksi pada saat pemotongan molekul DNA dalam proses rekombinasi dan splicing language merupakan model matematis dari tindakan enzim ligase pada saat penyisipan rantai molekul DNA (Lim, et al., 2011).

Penelitian tentang aplikasi splicing system dalam rekombinasi molekul DNA telah dilakukan diantaranya oleh Nor Haniza Sarmin dan Fong Wan Heng (2006) dalam judul penelitian "Mathematical Modelling of Splicing System" dan Fong Wan Heng et al (2008) dalam judul penelitian "Recognition of Simple Splicing Systems using SH-Automaton".

Permasalahan yang dibahas dalam paper ini adalah aplikasi splicing system, khususnya uniform splicing system, dalam proses rekombinasi molekul DNA pada satu kasus dengan penentuan molekul DNA dan enzim restriksi yang terlibat.

\section{LANDASAN TEORI}

\subsection{Substansi Genetika}

Setiap sel pada makhluk hidup memiliki inti sel yang mengandung kromosom-kromosom. Kromosom mengandung gen yang merupakan substansi genetika. Substansi genetika menentukan sifat-sifat makhluk hidup yang akan 
diwariskan pada keturunannya. Sebuah kromosom terdiri dari DNA dan protein. DNA merupakan persenyawaan kimia pembawa materi genetik. Sementara itu, protein penyusun kromosom terdiri atas protein histon yang bersifat basa dan protein nonhiston yang bersifat asam.

Deoxyribonucleic acid (DNA) atau asam deoksiribonukleat adalah suatu molekul besar yang kompleks dan terdiri atas dua rantai panjang yang saling berpilin membentuk suatu rantai atau untaian ganda (double helix). Kedua rantai mempunyai orientasi yang berlawanan (antiparalel). Rantai yang satu mempunyai orientasi $5^{\prime} \rightarrow 3^{\prime}$, sedangkan rantai yang lain berorientasi $3^{\prime} \rightarrow 5^{\prime}$.

\subsection{Enzim Retriksi dan Enzim Ligase}

Pada tahun 1960, Werner Arber dan Hamilton Smith menemukan enzim dari mikroba yang dapat memotong molekul DNA rantai ganda. Enzim tersebut dikenal dengan nama enzim restriksi atau enzim endonuklease restriksi.

Enzim restriksi merupakan enzim yang dapat memotong molekul DNA khususnya pada bagian gula-fosfat dalam nukleotida. Enzim restriksi akan mengenali dan memotong DNA hanya pada urutan nukleotida tertentu, biasanya sepanjang 4 hingga 6 pasang basa. Hasil dari masing-masing reaksi tersebut yakni dua buah potongan molekul DNA rantai ganda dengan ujung molekul DNA rantai tunggal. Ujung seperti ini yang dikenal dengan istilah sticky end atau cohesive ends.

Enzim ligase merupakan enzim yang mengkatalisis pembentukan ikatan fosfodiester antara ujung 5'-P dan 3'-OH pada DNA saat terjadinya rekombinasi molekul DNA. Secara biologis, enzim ligase diperlukan untuk menyambung potongan-potongan DNA. Enzim ligase diibaratkan sebagai lem yang menyambung DNA yang telah terpotong sehingga menjadi DNA yang fungsional.

\section{HASIL DAN PEMBAHASAN}

\subsection{Konsep Dasar Rekombinasi Molekul DNA}

Pada bagian ini akan dijelaskan variabel-variabel dalam proses rekombinasi. 
Ada beberapa Enzim yang berperan dalam proses rekombinasi DNA yaitu : Enzim Restriksi dan Enzim Ligase. Enzim restriksi merupakan enzim yang dapat memotong molekul DNA sepanjang 4 hingga 6 pasang basa.

Tabel 1 Jenis-Jenis Enzim Restriksi (Watson, 1983)

\begin{tabular}{|c|c|c|c|c|}
\hline Enzim & Sumber & $\begin{array}{c}\text { Urutan } \\
\text { Pengenalan }\end{array}$ & $\begin{array}{c}\text { Urutan } \\
\text { Pemotongan }\end{array}$ & Isoschizomers \\
\hline $\operatorname{AjnI}$ & $\begin{array}{l}\text { Acinetobacter } \\
\text { johnsonii R2 }\end{array}$ & $\begin{array}{l}\text { 5'-CCWGG } \\
3^{\prime}-G G \bar{W} C C\end{array}$ & $\begin{array}{l}5^{\prime}-\downarrow C C W G G \\
3^{\prime}-G G \bar{W} C C \uparrow\end{array}$ & $\begin{array}{l}\text { AorI, ApaORI, } \\
\text { ApyI, EcoRII, } \\
\text { MvaI, PspGI, } \\
\text { SleI, SspAI. }\end{array}$ \\
\hline Bfi57I & $\begin{array}{c}\text { Butyrivibrio } \\
\text { fibrisolvens } \\
\text { OB157 }\end{array}$ & $\begin{array}{l}5^{\prime}-G A T C \\
3^{\prime}-C T A G\end{array}$ & $\begin{array}{l}5^{\prime}-\downarrow G A T C \\
3^{\prime}-C T A G \uparrow\end{array}$ & $\begin{array}{l}\text { Bsp105I, } \\
\text { Bsp143I, } \\
\text { BspJI, } \\
\text { Bst } \mathrm{MBI}, \\
\text { CviAI, Kz09I, } \\
\text { NdeII, SsiBI, } \\
\text { MboI. }\end{array}$ \\
\hline Eco183II & $\begin{array}{l}\text { Escherichia coli } \\
\text { RFL1831 }\end{array}$ & $\begin{array}{l}5^{\prime}-C C S G G \\
3^{\prime}-G G \bar{S} C C\end{array}$ & $\begin{array}{l}5^{\prime}-\downarrow C C S G G \\
3^{\prime}-G G \bar{S} C C \uparrow\end{array}$ & $\begin{array}{l}\text { AhaI, AseII, } \\
\text { AsuC2I, BcnI, } \\
\text { BpuMI, CauII, } \\
\text { EcoHI, } \\
\text { HgiS221. }\end{array}$ \\
\hline ChaI & $\begin{array}{c}\text { Corynebacterium } \\
\text { halofytica }\end{array}$ & $\begin{array}{l}5^{\prime}-G A T C \\
3^{\prime}-C T A G\end{array}$ & $\begin{array}{l}5^{\prime}-G A T C \downarrow \\
3^{\prime}-\uparrow C T A G\end{array}$ & $\begin{array}{l}\text { BfuCI, } \\
\text { Bsp2095I, } \\
\text { BspKTGI, } \\
\text { BtkII, FnuCI, } \\
\text { NmeCI, SsiAI. }\end{array}$ \\
\hline FatI & $\begin{array}{c}\text { Flavobacterium } \\
\text { aquatile NL3 }\end{array}$ & $\begin{array}{l}5^{\prime}-C A T G \\
3^{\prime}-G T A C\end{array}$ & $\begin{array}{l}5^{\prime}-\downarrow C A T G \\
3^{\prime}-G T A C \uparrow\end{array}$ & Hin 1 II \\
\hline Eco $137 \mathrm{KI}$ & $\begin{array}{c}\text { Escherichia coli } \\
137 K\end{array}$ & $\begin{array}{l}5^{\prime}-C C N G G \\
3^{\prime}-G G \bar{N} C C\end{array}$ & $\begin{array}{l}5^{\prime}-\downarrow C C N G G \\
3^{\prime}-G G \bar{N} C C \uparrow\end{array}$ & SsoII, BssKI. \\
\hline Нpy57I & $\begin{array}{c}\text { Helicobacter } \\
\text { pylori } 51\end{array}$ & $\begin{array}{l}5^{\prime}-G T S A C \\
3^{\prime}-C A \bar{S} T G\end{array}$ & $\begin{array}{l}5^{\prime}-\downarrow G T S A C \\
3^{\prime}-C A \bar{S} T G \uparrow\end{array}$ & $\mathrm{NmuCI}$ \\
\hline Нру99I & $\begin{array}{c}\text { Helicobacter } \\
\text { pylori J99 }\end{array}$ & $\begin{array}{l}5^{\prime}-C G W C G \\
3^{\prime}-G C \bar{W} G C\end{array}$ & $\begin{array}{l}5^{\prime}-C G W C G \downarrow \\
3^{\prime}-\uparrow G C \bar{W} G C\end{array}$ & \\
\hline НруСH4I & $\begin{array}{l}\text { Helicobacter } \\
\text { pylori } \mathrm{CH} 4\end{array}$ & $\begin{array}{l}\text { 5'-CATG } \\
\text { 3'-GTAC }\end{array}$ & $\begin{array}{l}5^{\prime}-C A T G \downarrow \\
3^{\prime}-\uparrow G T A C\end{array}$ & Hsp92II \\
\hline
\end{tabular}




\begin{tabular}{|c|c|c|c|c|}
\hline MaeII & $\begin{array}{c}\text { Methanococcus } \\
\text { aeolicus }\end{array}$ & $\begin{array}{l}\text { 5'-GTNAC } \\
3^{\prime}-C A \bar{N} T G\end{array}$ & $\begin{array}{l}5^{\prime}-\downarrow G T N A C \\
3^{\prime}-C A \bar{N} T G \uparrow\end{array}$ & \\
\hline Sse9I & $\begin{array}{c}\text { Sporosarcina sp. } \\
9\end{array}$ & $\begin{array}{l}5^{\prime}-A A T T \\
\text { 3'-TTAA }\end{array}$ & $\begin{array}{l}5^{\prime}-\downarrow A A T T \\
3^{\prime}-T T A A \uparrow\end{array}$ & $\begin{array}{l}\text { MluCI, } \\
\text { Tsp590I. }\end{array}$ \\
\hline$T s c \mathrm{I}$ & $\begin{array}{c}\text { Thermus sp. } \\
491 A\end{array}$ & $\begin{array}{l}5^{\prime}-A C G T \\
3^{\prime}-T G C A\end{array}$ & $\begin{array}{l}5^{\prime}-A C G T \downarrow \\
3^{\prime}-\uparrow T G C A\end{array}$ & Tsp49I \\
\hline
\end{tabular}

Enzim ligase merupakan enzim yang mengkatalisis pembentukan ikatan fosfodiester antara ujung 5'-P dan 3'-OH pada DNA saat terjadinya rekombinasi molekul DNA.Secara biologis, enzim ligase diperlukan untuk menyambung potongan-potongan DNA.

\section{Splicing System dan Splicing Language(Head, 1987)}

Definisi 3.1 $S=(A, I, B, C)$ adalah splicing system dengan $A$ himpunan hingga alfabet, $I \subseteq A^{*}$ himpunan hingga awalan string, $B, C \subseteq A^{*}$ himpunan hingga triplet $(c, x, d)$ dengan $c, x, d \in A^{*}$. Masing-masing triplet dalam $B$ atau $C$ disebut pola. Untuk masing-masing triplet, string cxddisebut site dan string $x$ disebut crossing. Pola pada $B$ disebut pola kiri dan pola pada $C$ disebut pola kanan.

Definisi 3.2 $L(S)$ adalah bahasa yang dihasilkan oleh splicing system $S$ yang terdiri dari $w \in I$ dan semua string yang diperoleh dengan merangkaikan string $u c x f q$ dan $p e x d v$ ke Ldengan $u c x d v$, pexfq $\in L$ serta $(c, x, d)$ dan $(e, x, f)$ adalah pola dengan sisi yang sama (keduanya sama-sama pola kanan atau pola kiri). Bahasa $L$ adalah splicing language jika ada splicing system Sdengan $L=L(S)$. Bahasa $L$ yang dihasilkan oleh $S$ dinotasikan

$$
L(S)=\left\{w \in A^{*} \mid I \dot{\rightarrow} w\right\}(1)
$$

Definisi 3.3 Null-context splicing system adalah splicing system $S=(A, I, B, C)$ dengan masing-masing pola potongan di $B$ dan $C$ mempunyai bentuk $(1, x, 1)$. Bahasa $L$ dikatakan null-context splicing language jika ada null-context splicing systemSdengan $L=L(S)$. (Lim, S.J, et al., 2011). 
Pada kasus molekul DNA heliks ganda maka $S=\left(D, I \cup I^{\prime}, B, C\right)$ dengan $I \in M, B \in R, C \in R, I=\left\{w \in D^{*} \mid w^{\prime} \in I \cup I^{\prime}\right\} . \quad M$ adalah himpunan molekul DNA heliks ganda dan $R$ adalah himpunan enzim restriksi.

\section{Contoh}

Misalkan $S=\left(D, I \cup I^{\prime}, B, C\right)$ null-context splicing system. Misalkan $X$ adalah himpunan crossing di $B$ dan $Y$ adalah himpunan crossing di $C$, sehingga $S$ dapat ditulis menjadi $S=\left(D, I \cup I^{\prime}, X, Y\right)$. Pilih enzim EcoRII dengan urutan pemotongan pola kiri 5 ,

$$
B=\{(1,[c, g][c, g][a, t][g, c][g, c], 1),(1,[c, g][c, g][t, a][g, c][g, c], 1)\}
$$

atau

$$
X=\{[c, g][c, g][a, t][g, c][g, c],[c, g][c, g][t, a][g, c][g, c]\} \text { dan } C=Y=\emptyset .
$$

Definisi 3.4 Uniform splicing system adalah null-context splicing system $S=$ $(A, I, X, X)$ dengan terdapat $P \in \mathbb{Z}^{+}$sehingga $X=A^{P}$. Bahasa $L$ dikatakan uniform splicing language jika ada uniform splicing systemSdengan $L=L(S)$. (Lim, S.J, et al., 2011).

Pada kasus molekul DNA heliks ganda maka $S=\left(D, I \cup I^{\prime}, X, X\right)$ dengan $I \in M, X \in R, I=\left\{w \in D^{*} \mid w^{\prime} \in I \cup I^{\prime}\right\} . M$ adalah himpunan molekul DNA heliks ganda dan $R$ adalah himpunan enzim restriksi. $S$ dapat ditulis pula dengan $S=\left(D, I \cup I^{\prime}, X, \emptyset\right)$ atau $S=\left(D, I \cup I^{\prime}, \emptyset, X\right)$, sehingga penulisan $S$ dapat disederhanakan menjadi $S=\left(D, I \cup I^{\prime}, X\right)$.

\subsection{Rekombinasi molekul DNA}

Pada bagian ini akan dijelaskan proses rekombinasi molekul DNA pada berbagai kasus dengan penentuan molekul DNA yang mengandung gen pendonor dan penerima donor serta pemilihan enzim restriksi yang terlibat dan identifikasi kondisi tertentu yang menyebabkan suatu molekul DNA dapat dilakukan rekombinasi. 
i. Rekombinasi Molekul DNA Pada Kasus Gen Pendonor dan Gen Penerima Donor Dalam Dua Molekul DNA Dengan Peran 1 Buah Enzim Restriksi (Lim, et al., 2015)

Misalkan $S=\left(D, I \cup I^{\prime}, X\right)$ uniform splicing system dengan

$$
\begin{gathered}
\{[g, c][g, c][c, g][a, t][a, t][t, a][t, a][g, c][c, g] \\
I t, a][g, c][c, g][a, t][g, c][t, a][g, c][c, g][c, g], \\
{[a, t][c, g][g, c][c, g][g, c][t, a][a, t][t, a][g, c]} \\
[t, a][a, t][a, t][t, a][t, a][c, g][c, g][g, c][g, c][a, t]\}
\end{gathered}
$$

I menyatakan sub himpunan dari molekul DNA heliks ganda, dan enzim restriksi yang digunakan yaitu MluCI (tabel1) dengan urutan pemotongan pola kiri 5', $B=\{(1,[a, t][a, t][t, a][t, a], 1)\}$ atau dapat ditulis $X=\{[a, t][a, t][t, a][t, a]\}$.

Jika MluCI ditambahkan ke molekul DNA I maka diperoleh

$$
\begin{aligned}
& 5^{\prime}-G G C \downarrow A A T T G C T G C A G T G C C-3 \\
& 3^{\prime}-C C G T T A A \uparrow C G A C G T C A C G G-5
\end{aligned}
$$

dan

$$
\begin{aligned}
& 5^{\prime}-A C G C G T A T G T \downarrow A A T T C C G G A-3^{\prime} \\
& 3^{\prime}-T G C G C A T A C A T T A A \uparrow G G C C T-5
\end{aligned}
$$

Pemotongan molekul DNA rantai ganda tersebut dapat dilihat pula dengan orientasi berikut ini

$$
\begin{aligned}
& 5^{\prime}-G G C A C T G C A G C \downarrow A A T T G C C-3^{\prime} \\
& 3^{\prime}-C C G T G A C G T C G T T A A \uparrow C G G-5^{\prime}
\end{aligned}
$$

dan

$$
\begin{aligned}
& 5^{\prime}-T C C G G \downarrow \text { AATTACATACGCGT -3 } \\
& 3^{\prime}-\text { AGGCCTTAA } \uparrow \text { TGTATGCGCA-5' }
\end{aligned}
$$

sehingga $u_{1} c x c^{\prime} v_{1}, p_{1} c x c^{\prime} q_{1}, u_{2} c x c^{\prime} v_{2}, p_{2} c x c^{\prime} q_{2} \in I \quad$ dan $\quad u_{n}, v_{n}, p_{n}, q_{n} ; n=1,2$ merupakan potongan molekul DNA $I$ dengan $u_{1}=g g c, c=\varepsilon, x=$ aatt, $c^{\prime}=\varepsilon$, $v_{1}=$ gctgcagtgc $c, p_{1}=$ ggcactgcag $c, q_{1}=g c c$ dan $u_{2}=\operatorname{acg} \operatorname{cgtatg} t, v_{2}=c c g g a$ ,$p_{2}=$ tccgg,$q_{2}=$ acatacgcgt . 
Selanjutnya akan dilakukan penyambungan molekul DNA oleh enzim ligase pada kondisi kimiawi tertentu. Bahasa $L(S)$ yang dihasilkan oleh $S$ didefinisikan sebagai $L(S)=\left\{w \in I^{*} \mid S \dot{\rightarrow} w\right\}$.

Akan ditentukan bahasa yang sesuai dengan $S$. Diketahui $u_{1} c x c^{\prime} v_{1}, p_{1} c x c^{\prime} q_{1}, u_{2} c x c^{\prime} v_{2}, p_{2} c x c^{\prime} q_{2} \in I$.

a) Misal pilih salah satu potongan dari molekul pertama yaitu $u_{1}=g g c$.

Maka potongan dari molekul kedua yang dapat disambungkan dengan $u_{1}$ adalah $v_{2}=$ ccgga atau $q_{2}=$ acatacgcgt .

$\therefore u_{1} c x c^{\prime} v_{2}, p_{2} \operatorname{cxc}^{\prime} q_{1}, u_{1} c x c^{\prime} q_{2}, u_{2} c x c^{\prime} q_{1} \in L$.

b) Misal pilih salah satu potongan dari molekul pertama yaitu $u_{2}=$ acgcgtatg .

Maka potongan dari molekul kedua yang dapat disambungkan dengan $u_{2}$ adalah $v_{1}=$ gctgcagtgc $c$ atau $q_{1}=g c c$.

$\therefore u_{2} c x c^{\prime} v_{1}, p_{1} c x c^{\prime} q_{2}, u_{2} \operatorname{cxc}^{\prime} q_{1}, u_{1} \operatorname{cxc}{ }^{\prime} q_{2} \in L$

Berdasarkan proses uniform splicing system dan uniform splicing language diperoleh molekul DNA baru yaitu

$$
\begin{gathered}
5^{\prime}-\text { GGCAATTCCGGA-3' } \\
3^{\prime}-C C G T T A A G G C C T-5^{\prime} \\
5^{\prime}-G G C A A T T A C A T A C G C G T-3^{\prime} \\
3^{\prime}-C C G T T A A T G T A T G C G C A-5^{\prime}
\end{gathered}
$$

dan

$$
\begin{aligned}
& 5^{\prime}-\text { ACGCGTATGTAATTGCTGCAGTGCC-3' } \\
& 3^{\prime}-\text { TGCGCATACATTAACGACGTCACGG }-5
\end{aligned}
$$

Jadi, rekombinasi molekul DNA pada kasus gen pendonor dan gen penerima donor dalam dua molekul DNA dengan peran 1 buah enzim restriksi menghasilkan bahasa

$$
L(S)=\left\{u_{n} S v_{m}, p_{n} S q_{m}, u_{n} S q_{m} \mid u_{n}, p_{n}, v_{m}, q_{m} \in I ; n, m=1,2 ; n \neq m\right\}
$$


ii. Rekombinasi Molekul DNA Pada Kasus Gen Pendonor dan Gen

\section{Penerima Donor Dalam Satu Molekul DNA Dengan Peran 2 Buah Enzim}

Restriksi Dengan Pola Pemotongan yang Sama(Lim, et al., 2011)

Misalkan $S=\left(D, I \cup I^{\prime}, X\right)$ uniformsplicing systemdengan

$$
I=\begin{aligned}
& \{[a, t][a, t][g, c][a, t][t, a][c, g][g, c][g, c][c, g] \\
& [g, c][a, t][t, a][c, g][t, a][t, a][c, g][t, a][t, a]\}
\end{aligned}
$$

dan enzim restriksi yang digunakan yaitu MboIdan DpnIIdengan urutan pemotongan pola kiri 5',

$$
B=\{(1,[g, c][a, t][t, a][c, g], 1),(1,[g, c][a, t][t, a][c, g], 1)\}
$$

atau dapat ditulis $X=\{[g, c][a, t][t, a][c, g],[g, c][a, t][t, a][c, g]\}$.

Jika MboI dan DpnII ditambahkan ke molekul DNA I maka diperoleh

$$
\begin{aligned}
& 5^{\prime}-A A \downarrow G A T C G G C \downarrow G A T C T T C C T-3^{\prime} \\
& 3^{\prime}-\text { TTCTAG } \uparrow C C G C T A G \uparrow A A G G A-5^{\prime}
\end{aligned}
$$

Pemotongan molekul DNA rantai ganda tersebut dapat dilihat pula dengan orientasi berikut ini

$$
\begin{aligned}
& 5^{\prime}-A G G A A \downarrow G A T C G C C \downarrow G A T C T T-3^{\prime} \\
& 3^{\prime}-\text { TCCTTCTAG } \uparrow \text { CGGCTAG } \uparrow A A-5^{\prime}
\end{aligned}
$$

Sehingga $u c x c^{\prime} v, p c x c^{\prime} q \in I$ dan $u, v, p, q$ merupakan potongan molekul DNA $I$ dengan $u=a a, c=\varepsilon \Rightarrow c^{\prime}=\varepsilon, x_{1}=g a t c, v=y c x_{2} c^{\prime} z \Rightarrow y=g g c$, $x_{2}=$ gatc, $z=t t c t$ dan $p=\operatorname{aggaa}, q=d c x_{2} c^{\prime} e \Rightarrow d=g c c, e=t t$.

Selanjutnya akan dilakukan penyambungan molekul DNA oleh enzim ligase pada kondisi kimiawi tertentu. Bahasa $L(S)$ yang dihasilkan oleh $S$ didefinisikan sebagai $L(S)=\left\{w \in I^{*} \mid S \dot{\rightarrow} w\right\}$.

Akan ditentukan bahasa yang sesuai dengan $S$. Jika $u c x_{1} c^{\prime} v, p c x_{1} c^{\prime} q \in I$ maka $u c x_{1} c^{\prime} q, p c x_{1} c^{\prime} v \in L$.

a) $u c x_{1} c^{\prime} q=u x_{1} d x_{2} e$ karena $e$ merupakan potongan dari $z$ dan $x=x_{1}=x_{2}$ maka dapat ditulis $u x_{1} d x_{2} e=u x d x z$.

b) $p c x_{1} c^{\prime} v=p x_{1} y x_{2} z$ karena $x=x_{1}=x_{2}$ maka dapat ditulis $p x_{1} y x_{2} z=$ pxyxz.

$\therefore p c x c^{\prime} q, u c x_{1} c^{\prime} v \in I \Rightarrow u x d x z, p x y x z \in L$. 
Berdasarkan proses uniform splicing system dan uniform splicing language diperoleh molekul DNA baru yaitu

$$
\begin{aligned}
& 5^{\prime}-\text { AAGATCGGC - GATCTTCTT }-3^{\prime} \\
& 3^{\prime}-\text { TTCTAGCCG - -CTAGAAGAA }-5^{\prime}
\end{aligned}
$$

dan

$$
\begin{aligned}
& 5^{\prime}-\text { AAGATCGCC - -GATCTTCTT }-3^{\prime} \\
& 3^{\prime}-\text { TTCTAGCGG - -CTAGAAGAA }-5^{\prime}
\end{aligned}
$$

Jadi, rekombinasi molekul DNA pada kasus gen pendonor dan gen penerima donor dalam satu molekul DNA dengan peran 2 buah enzim restriksi dengan pola pemotongan sama yang dihasilkan oleh $S$ didefinisikan sebagai $L(S)=\left\{w \in I^{*} \mid S \rightarrow w\right\}$, pada proses di atas bahasa yang dihasilkan dapat pula dinyatakan oleh :

$$
L(S)=\left\{u(S y \cup S d)^{*} S z \mid u, y, d, z \in I\right\}
$$

iii. Rekombinasi Molekul DNA Pada Kasus Gen Pendonor dan Gen Penerima Donor Dalam Dua Molekul DNA Dengan Peran 2 Buah Enzim Restriksi Dengan Pola Pemotongan yang Sama(Lim, et al., 2011)

Misalkan $S=\left(D, I \cup I^{\prime}, X\right)$ uniform splicing system dengan

$$
\begin{aligned}
& \{[a, t][g, c][t, a][g, c][a, t][a, t][t, a][t, a][g, c] \\
I= & {[g, c][a, t][c, g][t, a][c, g][c, g][g, c][a, t][t, a], } \\
& {[c, g][c, g][t, a][a, t][g, c][g, c][a, t][c, g][t, a] } \\
& {[g, c][a, t][a, t][t, a][t, a][c, g][g, c][a, t][c, g]\} }
\end{aligned}
$$

dan enzim restriksi yang digunakan yaitu MluCIdan Tsp590Idengan urutan pemotongan pola kiri 5',

$$
B=\{(1,[a, t][a, t][t, a][t, a], 1),(1,[a, t][a, t][t, a][t, a], 1)\}
$$

atau dapat ditulis $X=\{[a, t][a, t][t, a][t, a],[a, t][a, t][t, a][t, a]\}$.

Jika MluCI dan Tsp590I ditambahkan ke molekul DNA I maka diperoleh

$$
\begin{aligned}
& 5^{\prime}-A G T G \downarrow \text { AATTGGACTCCGAT }-3^{\prime} \\
& 3^{\prime}-\text { TCACTTAA } \uparrow C C T G A G G C T A-5
\end{aligned}
$$

dan 


$$
\begin{aligned}
& 5^{\prime}-C C T A G G A C T G \downarrow \text { AATTCGAC - 3' } \\
& 3^{\prime}-G G A T C C T G A C T T A A \uparrow G C T G-5
\end{aligned}
$$

Pemotongan molekul DNA rantai ganda tersebut dapat dilihat pula dengan orientasi berikut ini

$$
\begin{aligned}
& 5^{\prime}-A T C G G A G T C C \downarrow A A T T C A C T-3 \\
& 3^{\prime}-T A G C C T C A G G T T A A \uparrow G T G A-5
\end{aligned}
$$

dan

$$
\begin{aligned}
& 5^{\prime}-G T C G \downarrow \text { AATTCAGTCCTAGG-3' } \\
& 3^{\prime}-C A G C T T A A \uparrow G T C A G G A T C C-5^{\prime}
\end{aligned}
$$

sehingga $u_{1} c x_{1} c^{\prime} v_{1}, p_{1} c x_{1} c^{\prime} q_{1}, u_{2} c x_{2} c^{\prime} v_{2}, p_{2} c x_{2} c^{\prime} q_{2} \in I \quad$ dan $u_{n}, v_{n}, p_{n}, q_{n} ; n=1,2$ merupakan potongan molekul DNA $I$ dengan $u_{1}=\operatorname{agtg}, c=\varepsilon, x_{1}=$ aatt , $c^{\prime}=\varepsilon, \quad v_{1}=$ ggactccgat,$\quad p_{1}=$ atcggagtcc,$q_{1}=$ cact dan $u_{2}=$ cctaggactg, $x_{2}=$ aatt,$v_{2}=$ cgac,$p_{2}=$ gtcg,$q_{2}=$ cagtcctagg.

Selanjutnya akan dilakukan penyambungan molekul DNA oleh enzim ligase pada kondisi kimiawi tertentu. Bahasa $L(S)$ yang dihasilkan oleh $S$ didefinisikan sebagai $L(S)=\left\{w \in I^{*} \mid S \dot{\rightarrow} w\right\}$.

Akan ditentukan bahasa yang sesuai dengan $S$. Diketahui $u_{1} c x_{1} c^{\prime} v_{1}, p_{1} c x_{1} c^{\prime} q_{1}, u_{2} c x_{2} c^{\prime} v_{2}, p_{2} c x_{2} c^{\prime} q_{2} \in I$.

a) Misal pilih salah satu potongan dari molekul pertama yaitu $u_{1}=\operatorname{agtg}$.

Maka potongan dari molekul kedua yang dapat disambungkan dengan $u_{1}$ adalah $v_{2}=$ cgac atau $q_{2}=$ cagtcctagg .

$\therefore u_{1} c x c^{\prime} v_{2}, p_{2} c x c^{\prime} q_{1}, u_{1} c x c^{\prime} q_{2}, u_{2} c x c q_{1} \in L$.

b) Misal pilih salah satu potongan dari molekul pertama yaitu $u_{2}=$ cctaggactg . Maka potongan dari molekul kedua yang dapat disambungkan dengan $u_{2}$ adalah $v_{1}=$ ggactccgat atau $q_{1}=$ cact .

$\therefore u_{2} c x c^{\prime} v_{1}, p_{1} c x c^{\prime} q_{2}, u_{2} c x c^{\prime} q_{1}, u_{1} c x c^{\prime} q_{2} \in L$

c) Misal pilih salah satu potongan dari molekul pertama yaitu $p_{1}=$ atcggagtcc . 
Maka potongan dari molekul kedua yang dapat disambungkan dengan $p_{1}$ adalah $v_{2}=c g a c$.

$\therefore p_{1} c x c^{\prime} v_{2}, p_{2} c x c^{\prime} v_{1} \in L$

$\therefore u_{n} c x c^{\prime} v_{n}, p_{n} c x c^{\prime} q_{n} \in I ; n=1,2 \Rightarrow u_{n} c x c^{\prime} v_{m}, p_{n} c x c^{\prime} q_{m}, u_{n} c x c^{\prime} q_{m}, p_{n} c x c^{\prime} v_{m} \in I$;

$n \neq m$.

Berdasarkan proses uniform splicing system dan uniform splicing language diperoleh molekul DNA baru yaitu

$$
\begin{aligned}
& 5^{\prime} \text { - AGTGAATTCGAC - } 3 \\
& \text { 3' - TCACTTAAGCTG - 5' } \\
& 5^{\prime} \text { - AGTGAATTCAGTCCTAGG-3' } \\
& 3^{\prime} \text {-TCACTTAAGTCAGGATCC - 5' } \\
& 5 \text { - ATCGGAGTCCAATTCGAC - } 3 \\
& 3^{\prime} \text { - TAGCCTCAGGTTAAGCTG-5' }
\end{aligned}
$$

dan

$$
\begin{aligned}
& 5^{\prime} \text { - ATCGGAGTCCAATTCAGTCCTAGG-3' } \\
& 3^{\prime} \text { - TAGCCTCAGGTTAAGTCAGGATCC - 5' }
\end{aligned}
$$

Bahasa $L(S)$ yang dihasilkan oleh $S$ yang didefinisikan sebagai $L(S)=$ $\left\{w \in I^{*} \mid S \dot{\rightarrow} w\right\}$ pada kasus gen pendonor dan gen penerima donor dalam dua molekul DNA dengan peran 2 buah enzim restriksi dengan pola pemotongan yang sama dapat dinyatakan sebagai bahasa $L(S)=\left\{w_{1} S w_{2} \mid w_{1}, w_{2} \in I\right\}$ dengan $w_{1}$ dan $w_{2}$ potongan dari molekul DNA yang berbeda.

\section{KESIMPULAN}

Berdasarkan hasil penelitian terhadap permasalahan rekombinasi molekul DNA, maka dapat ditarik simpulan sebagai berikut.

1. Rekombinasi molekul DNA rantai ganda menggunakan uniform splicing system dan uniform splicing language menghasilkan bahasa $L(S)$ yang berbeda-beda bergantung pada penentuan molekul DNA yang mengandung gen pendonor dan penerima donor serta pemilihan enzim restriksi yang terlibat. 
2. Rekombinasi molekul DNA dapat dilakukan pada molekul DNA yang memuat potongan molekul DNA yang dapat dikenali oleh suatu enzim restriksi.

\section{DAFTAR PUSTAKA.}

Head, T, Formal Language Theory and DNA, Bulletin of Mathematical Biology 49 (1987), 737-759.

Lim, S.J., Karimi, F., Sarmin, N.H., dan Fong, W.H., Mathematical Modelling of Some Null-Context and Uniform Splicing System, Journal of Fundamental Sciences, 7(2) (2011).

Sunthornwata, R., Moorea, E.J., dan Temtanapat, Y., Detecting And Classifying Mutations In Genetic Code With An Application To $\beta$-Thalassaemia, Science Asia, 37 (2011), 51-61.

Watson, J. D., Tooze, J. dan Kurtz, D. T., Recombinant DNA: A Short Course, Freeman, New York, 1983.

Yuwono, T., Biologi Molekular, Penerbit Erlangga, Yogyakarta, 2005. 
